\title{
PENGETAHUAN IBU HAMIL TENTANG PERAWATAN PAYUDARA DI DESA MOJO KECAMATAN MOJO KABUPATEN KEDIRI
}

\author{
Susiani Endarwati ${ }^{1}$
}

${ }^{1}$ Akademi Kebidanan Dharma Husada Kediri Jawa Timur

\begin{abstract}
Abstrak
Perawatan payudara selama kehamilan adalah salah satu bagian penting yang harus diperhatikan sebagai persiapan dalam pemberian ASI, kenapa ASI eksklusif sangat penting karena pada usia tersebut sesungguhnya bayi belum mampu untuk mencerna makanan selain ASI. Tujuan penelitian ini adalah untuk mengetahui pengetahuan ibu hamil tentang perawatan payudara di Desa Mojo Kecamatan Mojo Kabupaten Kediri.

Penelitian ini menggunakan desain penelitian deskriptif dengan metode cross sectional. Populasi adalah semua ibu hamil di Desa Mojo Kecamatan Mojo Kabupaten Kediri. Dengan teknik total sampling didapatkan sampel sebanyak 36 responden. Variabel dalam penelitian ini adalah variabel tunggal yaitu pengetahuan ibu hamil tentang perawatan payudara. Pengumpulan data dengan menggunakan kuesioner yang bersifat tertutup. Pengolahan data meliputi editing, coding, scoring, tabulating kemudian data dianalisa dengan persentase.

Hasil penelitian menunjukkan dari 36 responden yang diteliti, didapatkan 23 responden $(63,9 \%)$ memiliki pengetahuan baik tentang perawatan payudara di Desa mojo kecamatan Mojo Kabupaten Kediri.

Berdasarkan penelitian menunjukkan pengetahuan ibu tetang perawatan payudara adalah baik. Maka diharapkan ibu hamil mau meningkatkan pengetahuannya tentang perawatan payudara selama kehamilan karena melihat pentingnya dan sangat bermanfaat untuk ibu dan bayinya serta bersedia untuk melakukan perawatan payudara dirumah. Tenaga kesehatan dan lintas sektor lebih meningkatkan penyuluhan tentang pentingnya perawatan payudara
\end{abstract}

\section{Kata Kunci: Pengetahuan, Ibu Hamil, Perawatan Payudara}

Korespondensi: Jl. Penanggungan No 41 A Kediri Jawa Timur HP: 085646667282, email: susianiendarwati1@gmail.com 


\section{Pendahuluan}

Kehamilan didefinisikan sebagai fertilisasi atau penyatuan dari spermatozoa dan ovum dan dilanjutkan dengan nidasi atau implantasi hingga lahirnya bayi. Bila dihitung dari saat fertilitas hingga lahirnya bayi, kehamilan normal akan berlangsung dalam waktu 40 minggu atau 10 bulan atau 9 bulan menurut kalender internasional. (Prawirohardjo, 2014:213)

Kondisi kehamilan membuat banyak perubahan pada wanita. Dilihat dari segi fisik perubahan perubahan itu antara lain berat badan bertambah, perubahan pada kulit, dan perubahan pada payudara. Perubahan ini mendukung payudara untuk memproduksi ASI sehingga ibu bisa menyusui bayinya setelah lahir, saat hamil bentuk payudara juga menjadi lebih besar, termasuk daerah putting juga memiliki banyak kelenjar minyak keringat yang berfungsi agar kulit putting senantiasa lembut, lentur, dan terlindungi dari iritasi akibat hisapan bayi. Minyak yang timbul dari kelenjar ini juga membunuh kuman di sekitar putting. Sementara itu, ASI sendiri dapat membunuh kuman. Selama hamil, putting menjadi lebih besar. Kadang, kelenjar minyak di daerah ini menjadi terlihat besar seperti benjolan di daerah areola. (Saryono \& Pramitasari, 2014:50)

Masa kehamilan kadang menimbulkan perasaan lesu dan lelah sehingga muncul rasa malas. Walaupun demikian ibu hamil hendaknya tetap merawat tubuhnya, misalnya menjaga kebersihan gigi, rambut, kulit, dan pakaian yang dikenakan sesuai dan bersih, juga merawat payudara. Mengapa perawatan payudara penting? Karena pada tubuh yang sehat, bersih, terawat pada akhirnya akan menimbulkan rasa segar dan gairah hidup. Sehingga akan mengusir rasa lelah itu sendiri. Khususnya dalam hal merawat payudara baik selama masa kehamilan maupun setelah bersalin akan menjaga bentuk payudara juga akan memperlancar ASI. (Bandiyah, 2009:41)

Pada tahun 2010 UNICEF menyebutkan bukti ilmiah yang dikeluarkan oleh jurnal Pediatrics. Terungkap data di dunia ibu menyusui mengalami masalah menyusui sekitar 17.230.142 juta jiwa yang terdiri dari putting lecet $56,4 \%$, bendungan payudara $36,12 \%$, dam mastitis $7,5 \%$.

Perawatan payudara sebaiknya dilakukan sejak selama masa akhir akhir kehamilan, terutama kehamilan bulan ketujuh. Selama masa menyusui sebaiknya payudara harus selalu dibersihkan dengan air bersih. Perawatan payudara dapat dilakukan oleh ibu secara mandiri. (Widuri, 2013:175)

\section{Metode}

Desain penelitian yang digunakan dalam penelitian ini adalah rancangan penelitian deskriptif, dengan pendekatan cross sectional. Populasi dalam penelitian ini adalah semua ibu hamil di Desa Mojo Kecamatan Mojo Kabupaten Kediri sebanyak 36 orang 
Hasil

a. Karakteristik Responden Berdasarkan Umum

Tabel IV.1 Karakteristik Responden Berdasarkan Umur Di Desa Mojo Kecamatan Mojo Kabupaten Kediri

\begin{tabular}{ccc}
\hline Umur & Frekuensi & Prosentase (\%) \\
\hline$<20$ tahun & 2 & 5,5 \\
\hline $20-35$ tahun & 30 & 83,4 \\
\hline$>35$ tahun & 4 & 11,1 \\
\hline Jumlah & 36 & 100 \\
\hline
\end{tabular}

Berdasarkan tabel IV.I dari 36 responden yang diteliti mayoritas responden berumur 20 -35 tahun sebanyak 30 orang $(83,4 \%)$

b. Karakteristik Responden Berdasarkan Pendidikan

Tabel IV.2 Karakteristik Responden Berdasarkan Pendidikan Di Desa Mojo Kecamatan Mojo Kabupaten Kediri

\begin{tabular}{ccc}
\hline Pendidikan & Frekuensi & Prosentase (\%) \\
Tidak Tamat SD & 0 & 0 \\
SD & 5 & 13,9 \\
SMP & 16 & 44,5 \\
SMA & 14 & 38,9 \\
PT & 1 & 2,7 \\
Jumlah & 36 & 100 \\
\hline
\end{tabular}

Berdasarkan tabel IV.2 dari 36 responden yang diteliti mayoritas responden berpendidikan SMP sebanyak 16 orang $(44,5 \%)$

c. Karakteristik Responden Berdasarkan Pekerjaan

Tabel IV.3 Karakteristik Responden Berdasarkan Pekerjaan Di Desa Mojo Kecamatan Mojo Kabupaten Kediri

\begin{tabular}{ccc}
\hline Pekerjaan & Frekuensi & Prosentase (\%) \\
TNI/POLRI & 0 & 0 \\
PNS & 1 & 2,9 \\
Swasta & 2 & 5,5 \\
IRT ( Ibu Rumah & 31 & 86,1 \\
Tangga) & 2 & 5,5 \\
Wiraswasta & 36 & 100 \\
Jumlah & & \\
\hline
\end{tabular}

Berdasarkan tabel IV.3 dari 36 responden yang diteliti mayoritas responden pekerjaan nya sebagai IRT (Ibu Rumah Tangga) sebanyak 31 orang $(86,4 \%)$ 


\section{d. Karakteristik Responden Berdasarkan Sumber Informasi \\ Tabel IV.4 Karakteristik Responden Berdasarkan Sumber \\ Informasi tentang Perawatan Payudara Di Desa Mojo Kecamatan Mojo Kabupaten Kediri}

\begin{tabular}{ccc}
\hline $\begin{array}{c}\text { Sumber } \\
\text { informasi } \\
\text { pernah }\end{array}$ & Frekuensi & Prosentase (\%) \\
diperoleh dari & & \\
Tenaga Kesehatan & 5 & 13,9 \\
Majalah & 0 & 0 \\
TV/Radio & 0 & 0 \\
Orang Lain & 4 & 11,1 \\
Baca Buku & 0 & 0 \\
Tidak Pernah & 27 & 75 \\
Jumlah & 36 & 100 \\
\hline
\end{tabular}

Berdasarkan tabel IV.4 dari 36 responden yang diteliti mayoritas responden mayoritas responden tidak pernah memperoleh informasi tentang perawatan payudara selama kehamilan sebanyak 27 orang $(75 \%)$

\section{Data Khusus}

Pengetahuan Ibu Hamil Tentang Perawatan Payudara

Tabel IV.5 Distribusi Frekuensi Pengetahuan ibu hamil tentang Perawatan Payudara Di Desa Mojo Kecamatan Mojo Kabupaten Kediri.

\begin{tabular}{ccc}
\hline Kriteria & Frekuensi & Prosentase (\%) \\
Baik & 23 & 63,9 \\
Cukup & 13 & 36,1 \\
Kurang & 0 & 0 \\
Jumlah & 36 & 100 \\
\hline
\end{tabular}

Berdasarkan tabel IV.5 dari 36 responden yang diteliti pengetahuan tentang perawatan payudara di Desa Mojo Kecamatan Mojo Kabupaten Kediri didapatkan 23 responden $(63,9 \%)$ ibu hamil pengetahuannya dalam kategori baik, 13 responden $(36,1 \%)$ dan dalam kategori cukup.

\section{Diskusi}

\section{Pengetahuan Ibu Hamil Tentang Perawatan Payudara}

Berdasarkan tabel VI.5 diketahui pengetahuan ibu hamil tentang perawatan payudara di Desa Mojo Kecamatan Mojo Kabupaten Kediri sebagian besar dalam kategori baik yaitu sebanyak 23 responden $(63,9 \%)$, dan kategori cukup sebanyak 13 responden $(36,1 \%)$.

Pengetahuan adalah merupakan hasil "tahu" dan ini terjadi setelah 
orang mengadakan penginderaan terhadap suatu objek tertentu. (Wawan \& Dewi, 2016:11).

Dengan semakin banyak responden memanfaatkan indera yang dimilikinya untuk proses belajar, maka semakin banyak pula pengetahuan yang akan diperoleh, dan sebagian besar responden sudah mengetahui tentang perawatan payudara.

Perlu diketahui pengetahuan sangat erat kaitannya dengan pendidikan dimana diharapkan seseorang dengan pendidikan tinggi, maka orang tersebut akan semakin luas pengetahuannya. Namun perlu ditekankan bahwa seseorang yang berpendidikan rendah tidak berarti mutlak berpengetahuan rendah.

Berdasarkan hasil penelitian didapatkan sebagian besar responden berumur 20-35th. Hal ini sebagai akibat dari pengalaman dan kematangan jiwanya. Kemampuan dalam menerima informasi dapat diserap secara maksimal karena pada umur tersebut lebih matang dalam berfikir dan dapat memotivasi diri memperoleh pengetahuan yang sebanyak-banyaknya.

Pada dasarnya ibu hamil sudah mengetahui bahwa perawatan payudara sangat penting untuk persiapan pemberian ASI dimana perawatan payudara dapat dilakukan sejak dini yaitu pada saat kehamilan, akan tetapi banyak dari ibu yang tidak tau tentang prosedur perawatan payudara.

Pengetahuan tentang manfaat perawatan payudara masih banyak ibu hamil yang belum memahami bahwa perawatan payudara bertujuan untuk menjaga kebersihan payudara terutama kebersihan puting susu, melenturkan dan menguatkan putting susu sehingga memudahkan bayi untuk menyusu, merangsang kelenjar-kelenjar air susu sehingga ASI banyak dan lancar, dapat mendeteksi kelainan-kelainan payudara secara dini dan melakukan upaya untuk mengatasinya, dam mempersiapkan mental (psikis) ibu untuk menyusui. Hal ini menyebabkan mereka memiliki pengertian yang salah tentang manfaat perawatan payudara sehingga pada responden justru enggan melakukan perawatan payudara.

\section{Simpulan}

Diharapkan ibu hamil mau lebih meningkatkan pengetahuannya tentang perawatan payudara selama kehamilan, selain itu pentingnya peran penyuluh kesehatan dalam hal ini adalah tenaga kesehatan khususnya bidan desa tersebut untuk lebih meningkatkan lagi pemberian penyuluhan khususnya tentang perawatan payudara kepada para ibu tidak hanya ibu hamil tetapi juga kepada wanita pasangan usia subur, para kader dan tokoh masyarakat.

\section{Daftar Pustaka}

Ariani, A. Putri. 2014. Aplikasi Metodologi Penelitian Kebidanan Dan Kesehatan Reproduksi. Yogyakarta: Nuha Medika

Asih, Yusari \& Risneni. 2016. Buku Ajar Asuhan Kebidanan Nifas Dan Menyusui. Jakarta: Trans Info Media

Bandiyah, Siti. 2009. Kehamilan, Persalinan Dan Gangguan Kehamilan. Yogyakarta: Nuha Medika 
Budiman \& Agus. 2013. Kapita Selekta Kuesioner. Jakarta Selatan: Salemba Medika

Departemen Pendidikan. 2008. Kamus Besar Bahasa Indonesia

Hani, Ummi. 2010. Asuhan Kebidanan Pada Kehamilan Fisiologis. Jakarta: Salemba Medika

Hidayat, A. A. 2014. Metode Peneltian Kebidanan Dan Teknik Analisis. Jakarta: Salemba Medika

Hikmawati, I. 2011. Promosi Kesehatan Untuk Kebidanan. Yogyakarta: Nuha Medika

Notoatmodjo, Soekidjo. 2012. Ilmi Kesehatan Metode Penelitian Kesehatan. Jakarta: Rineka Cipta

Nugroho, Taufan. et al. 2014. Buku Ajar Asuhan Kebidanan 3 Nifas. Yogyakarta: Nuha Medika

Nursalam, 2011. Konsep Penerapan Metodologi Penelitian Ilmu Keperawatan. Jakarta: Salemba Medika

Prawirohardjo, Sarwono. 2014. Ilmu Kebidanan. Jakarta: Bina Pustaka

Saryono \& Pramitasari, R. Dyah. 2014. Perawatan Payudara. Yogyakarta: Nuha Medika

Sugiyono, 2017. Metode Penelitian Kualitatif, Kuantitatif $R \& D$. Bandung: Alfabeta

Sujarweni, V. Wiratna. 2014. Metodologi Penelitian Keperawatan. Jakarta: Gava Medika
Suryani, Eko. 2008. Pendidikan Kesehatan Bagian Dari Promosi Kesehatan. Yogyakarta: Fitramaya

Wawan \& M. Dewi. 2016. Pengetahuan, Sikap Dan Perilaku Manusia. Yogyakarta: Nuha Medika

Waryana. 2016. Promosi Kesehatan, Penyuluhan dan Pemberdayaan Masyarakat. Yogyakarta: Nuha Medika

Weni, Kristiyanasari. 2011. ASI, Menyusui dan SADARI. Yogyakarta: Nuha Medika

Widuri, Hesti. 2013. Cara Mengelola ASI Eksklusif Bagi Ibu Bekerja. Yogyakarta: Pustaka Baru

Ardyan, R. Nevyda. 2014. Hubungan frekuensi dan durasi pemberian ASI dengan kejadian bendungan ASI pada ibu nifas. [online] 4, http://www.repository.poltekkesmajapah it.ac.id [08 maret 2018]

Badan Kependudukan Dan Keluarga Berencana Nasional. 2017. Survei Demograf Dan Kesehatan Indonesia 2017. http://kesga kemkes.go.id /image/pedoman/laptahl\%2520TA\%252 02016\%2520 Dit [05 maret 2018]

D.S. Sowito. M. 2009. Pengertian ibu hamil. [online] 4, http://kabardunia.com/healt/1720_penge rtian_ibu_hamil.html [11 maret 2018]

Dokter, Alo. 2010. Perubahan bentuk payudara pada ibu hamil. [online] 3, [11 maret 2018]

Satria, Pradika. 2017. Anatomi payudara. [online] 1, https://www.dictio.id/t/bagaimanaanatomi-payudara-manusia/5960 [11 maret 2018] 
Siahaan, Puganda. 2017. Pengetahuan Dan Pengalaman Dari Segi Teori. [online] 1, http://www.academia.edu/24747077/pen getahuan_dan_pengalaman_dari_segi_te ori [11 maret 2018] 